\title{
Three-plant stubble (Family: Fabaceae) as a substrate for cultivation of Pleurotus ostreatus (Jacq.) P. Kummer., in Mexico
}

\author{
Maricela Cayetano-Catarino \\ Higher School of Natural Sciences, Autonomous University of Guerrero, Mexico \\ Teodoro Bernabé-González* \\ Higher School of Natural Sciences, Autonomous University of Guerrero, Mexico \\ Gadiel Bernabé-Villanueva \\ Higher School of Natural Sciences, Autonomous University of Guerrero, Mexico \\ Adalid Romero-Flores \\ Higher School of Natural Sciences, Autonomous University of Guerrero, Mexico \\ *Corresponding author. E-mail: teobernaglez@hotmail.com
}

\begin{abstract}
Mushroom cultivation is an economically feasible bio-technological process for conversion of various agricultural by-products. In Mexico, a large quantity of lignocellulosic residues is generated and several of them have been used as a substrate in the cultivation of Pleurotus spp. Thus, high nutritional value food is produced at a relatively low cost. In this study, fermented chickpea stubble (Cicer arietinum L.); bean (Phaseolus vulgaris L.) and peanut (Arachis hypogaea L.) stubble sun-dried were used as a substrate for growing a strain of Pleurotus ostreatus (Jacq.) P. Kummer. (IE-8). On the chickpea stubble, the spawning was carried out on three, five and seven days of fermentated (FCS-3, FCS-5 and FCS-7, respectively) substrate. Highest productivity was obtained on the FCS-3 substrate with the formation of first primordia between 15 and 17 days; crop cycle between 44 to 49 days, with $156 \%$ of biological efficiency (BE), $46.8 \%$ of yield $(Y)$ and $3.3 \%$ of production rate (PR). In the other treatments, forming first primordia was between 16 to 35 days, crop cycles between 43 and 61 days, with BE from $76.2 \%$ to $130.2 \%$, Y between $16.8 \%$ to $39.0 \%$ and PR between $1.7 \%$ to $2.9 \%$. Stubbles studied can be used as a substrate for the cultivation of the strain IE-8 on a small to large scale in the regions where they are generated, mainly the stubble of the chickpea plant.
\end{abstract}

Keywords: Agricultural by-products, Edible mushrooms, Mushroom cultivation, Pleurotus ostreatus

\section{INTRODUCTION}

Pleurotus species are present in tropical and subtropical forests around the world and can be cultivated artificially due to their high ability to colonize and degrade a wide variety of substrates containing cellulose, hemicellulose, and lignin, which are used for development, besides having fast mycelial growth and fruiting with low production cost (Pokhrel et al., 2013). On the other hand, the cultivation of Pleurotus species has increased because they have nutritional and medicinal values (Fernandes et al., 2015). Commercial cultivation of Pleurotus spp., ranks second worldwide after Agaricus spp. (Royse et al., 2017). In Mexi$\mathrm{co}$, mushroom production (Pleurotus spp.) is $4.76 \%$ (Martinez-Carrera et al., 2016) of the total that is mainly produced in Brazil, Colombia, Argentina and Guatemala (Royse and Sánchez, 2017).

\section{Article Info}

https://doi.org/10.31018/

jans.vi. 2270

Received: May 2, 2020

Revised: May 16, 2020

Accepted: May 21, 2020

\section{How to Cite}

Cayetano-Catarino, M. et al. (2020). Three-plant stubble (Family: Fabaceae) as a substrate for cultivation of Pleurotus ostreatus (Jacq.) P. Kummer., in Mexico. Journal of Applied and Natural Science, 12(2): $156-158$.

https://doi.org/10.31018/ jans.vi.2270
In Mexico, various agricultural by-products have been used as a substrate for the cultivation of Pleurotus spp. using Mexican or commercial strains (Mora and Martínez-Carrera, 2007). In the agricultural cycle 2018, chickpea (Cicer arietinum) stood out among other crops in eight states with a production of $52,622.71$ tons, also crop beans (Phaseolus vulgaris) and peanut (Arachis hypogaea) on 32 and 25 states with a production of $1 ' 222,890.45$ tons and $91,109.3$ tons, respectively (SIAP, 2018).

In this study, the potential of chickpea, bean and peanut stubble was evaluated when growing a strain of Pleurotus ostreatus (Jacq.) P. Kummer., to establish its possible production on a small and large scale in regions where these stubble occur.

\section{MATERIALS AND METHODS}

Biological material and spawn: Strain Pleurotus ostreatus (IE-8) was donated by the Institute of 
Ecology, Xalapa, Veracruz, Mexico. It was replanted and kept in Petri dishes in medium containing malt extract and agar (MEA) and incubated in darkness at $28^{\circ} \mathrm{C}$. Wheat grains (Triticum aestivum L.) with $45 \%$ humidity were used to prepare the spawn and they were sterilized at $121^{\circ} \mathrm{C}$ for 1 $\mathrm{h}$ in polypropylene bags (ca. $250 \mathrm{~g} / \mathrm{bag}$ ). After cooling the grains, $1 \mathrm{~cm}^{2}$ of MEA with previously developed mycelium was added to each bag; then, they were incubated in a dark room between $28^{\circ} \mathrm{C}$ and $29^{\circ} \mathrm{C}$ for two weeks (Gaitán-Hernández et al., 2002).

The experiment was conducted in a pilot plant of the biotechnology laboratory of edible and medicinal mushrooms of the Higher School of Natural Sciences dependent on the Autonomous University of Guerrero, Mexico. Stubbles of the three plants were obtained from farmland in the central region of the state of Guerrero and fragmented into segments between 4 to $6 \mathrm{~cm}$ long. Chickpea plants were obtained green and wet, so they were fermented aerobically for 7 days. Stubbles from the bean and peanut were obtained semi-humid and then sun-dried for 2 days. After, they were moistened and covered with plastic for $18 \mathrm{~h}$.

Treatments and spawning: The following treatments were prepared: 1. Fermented chickpea stubble 3 days (FCS-3), 2. Fermented chickpea stubble 5 days (FCS-5), 3. Fermented chickpea stubble 7 days (FCS-7), 4. Bean stubble (BS) and 5. Peanut stubble (PS). All substrates were pasteurized in the water at $80^{\circ} \mathrm{C}$ for $1 \mathrm{~h}$. Once cold, 4 $\mathrm{kg}$ of the wet weight of each substrate were placed inside $50 \times 70 \mathrm{~cm}$ polyethylene bags and the spawn (ca. $250 \mathrm{~g}$ wet) was added homogeneously. Five replicates per treatment were prepared.
Incubation and crops: Inoculated bags were incubated in the dark at room temperature between $27^{\circ} \mathrm{C}$ and $29^{\circ} \mathrm{C}$ and placed on metal shelves. With the formation of first fruiting primordia, the plastic cover was removed and the environmental conditions maintained were natural lighting $(11 \pm 1 \mathrm{~h}$ light / $11 \pm 1 \mathrm{~h}$ dark), relative humidity between $80 \%$ and $85 \%$ and temperature between $25^{\circ} \mathrm{C}$ and $28^{\circ} \mathrm{C}$, with ventilation provided by two electric air extractors.

Evaluation of the production of fruiting bodies: The parameters evaluated were: days in the formation of primordia; total crops days counted from spawning; fresh weight of basidiocarps in three harvests; biological efficiency (BE = fresh weight of basidiocarps harvested/dry weight substrate); yield $(Y=$ fresh weight of basidiocarps/fresh weight substrate) and production rate $(P R=B E /$ total days of production). BE, $\mathrm{Y}$, and $\mathrm{PR}$ are expressed in percentages.

Experimental design and statistical analysis: The design was completely random. The obtained values were processed by an analysis of variance and to determine the differences between treatment means, Tukey's multiple range test $(\alpha=$ 0.05) was applied.

\section{RESULTS AND DISCUSSION}

The formation of first primordia was earlier in FCS -3 treatment, requiring an average of 15.8 days and was statistically significant at the other treatments (16.6 to 28.8 days). In the formation of seconds and third primordia, there were no significant differences between treatments, except in BS treatment. The total crops cycle was between 44.2 to 47.4 days, except in BS treatment that took 58

Table 1. Average days in the formation of fruiting primordia and total crops cycle obtained in the cultivation of IE-8 strain of $P$. ostreatus.

\begin{tabular}{lllll}
\hline Treatments & \multicolumn{3}{l}{$\begin{array}{l}\text { Appearance of primordia (days } \pm \sigma \text { ) after } \\
\text { spawning }\end{array}$} & \multicolumn{2}{l}{ TCC $^{1}$} \\
\cline { 2 - 4 } & First & Second & Third & \\
\hline Fermented chickpea stubble 3 days (FCS-3) & $15.8 \pm 1.0 \mathrm{c}^{*}$ & $29.6 \pm 2.4 \mathrm{~b}$ & $42.8 \pm 2.2 \mathrm{~b}$ & $46.8 \pm 2.2 \mathrm{~b}$ \\
Fermented chickpea stubble 5 days (FCS-5) & $16.6 \pm 0.5 \mathrm{bc}$ & $31.4 \pm 1.3 \mathrm{~b}$ & $43.4 \pm 1.1 \mathrm{~b}$ & $47.4 \pm 1.1 \mathrm{~b}$ \\
Fermented chickpea stubble 7 days (FCS-7) & $18.2 \pm 1.0 \mathrm{bc}$ & $29.2 \pm 1.0 \mathrm{~b}$ & $40.2 \pm 1.0 \mathrm{~b}$ & $44.2 \pm 1.1 \mathrm{~b}$ \\
Bean stubble (BS) & $28.8 \pm 3.8 \mathrm{a}$ & $42.8 \pm 4.2 \mathrm{a}$ & $54.0 \pm 5.1 \mathrm{a}$ & $58.0 \pm 5.1 \mathrm{a}$ \\
Peanut stubble (PS) & $20.6 \pm 3.1 \mathrm{~b}$ & $31.8 \pm 2.4 \mathrm{~b}$ & $41.6 \pm 4.1 \mathrm{~b}$ & $45.4 \pm 3.8 \mathrm{~b}$ \\
\hline
\end{tabular}

${ }^{1} \mathrm{TCC}=$ total crops cycle. ${ }^{*}$ Different letters in the same column indicate statistical differences between mean values according to Tukey's multiple range test $(\alpha=0.05)$.

Table 2. Averages in productivity evaluation achieved in the cultivation of IE-8 strain of $P$. ostreatus.

\begin{tabular}{|c|c|c|c|c|c|}
\hline Treatments & $\begin{array}{ll}\text { Sustrates } & \text { dry } \\
\text { weight }(g) & \end{array}$ & $\begin{array}{l}\text { Total weight } \\
(\mathrm{g} \pm \sigma)\end{array}$ & $\begin{array}{l}\text { Biological effi- } \\
\text { ciency }(\% \pm \sigma)\end{array}$ & Yield $(\% \pm \sigma)$ & $\begin{array}{l}\text { Production } \\
\text { rate }(\% \pm \sigma)\end{array}$ \\
\hline FCS-3* & 1200 & $1872 \pm 187.5 a^{\star \star}$ & $156 \pm 15.6$ a & $46.8 \pm 4.6 \mathrm{a}$ & $3.3 \pm 0.4 \mathrm{a}$ \\
\hline FCS-5 & 1198 & $1560 \pm 119.4 \mathrm{~b}$ & $130.2 \pm 9.9 b$ & $39 \pm 2.9 \mathrm{~b}$ & $2.7 \pm 0.2 b$ \\
\hline FCS-7 & 1197 & $1510 \pm 41.8 \mathrm{~b}$ & $126.1 \pm 3.4 b$ & $37.8 \pm 1.0 \mathrm{~b}$ & $2.9 \pm 0.1 \mathrm{ab}$ \\
\hline BS & 952 & $935.4 \pm 178.1 \mathrm{c}$ & $98.3 \pm 18.7 \mathrm{c}$ & $23.4 \pm 4.4 \mathrm{c}$ & $1.7 \pm 0.3 \mathrm{c}$ \\
\hline PS & 881 & $671 \pm 97 \mathrm{~d}$ & $76.2 \pm 11 \mathrm{c}$ & $16.8 \pm 2.4 \mathrm{~d}$ & $1.7 \pm 0.3 \mathrm{c}$ \\
\hline
\end{tabular}

${ }^{*}$ Abbreviations corresponding to the treatments in Table 1. ${ }^{* *}$ Different letters in the same column indicate statistical differences between mean values according to Tuke's multiple test $(\alpha=0.05)$. 
days (Table 1).

FCS-3 treatment reached the highest values obtaining an average of $1872 \mathrm{~g}$ of fresh mushrooms in three harvests; BE of $156 \%, Y$ of $46.8 \%$ and PR of $3.3 \%$ and was significantly different from the rest of treatments. The fresh weight of mushrooms in the other treatments ranged from $671 \mathrm{~g}$ to $1560 \mathrm{~g}$; BE between $76.2 \%$ and $130.2 \%$; $Y$ between $16.8 \%$ and $39 \%$; PR between $1.7 \%$ and $2.9 \%$ (Table 2).

The values reached on FCS are higher than those obtained when four species of Pleurotus, $P$. djamor, $P$. platypus, $P$. florida and $P$. eous were cultivated on chickpea stubble and presented the first primordia between 15 to 19 days, total crops cycle from 34 to 41 days, BE between $48.0 \%$ and $81.2 \%$ (Deshmukh and Deshmukh, 2016) or when chickpea straw was used as main materials and cotton seed hulls (Gossypium sp.), olive press cake (Olea europea L.), sunflower press cake (Helianthus annuus L.) and sugar beet pulp (Beta vulgaris L.) were used as additive materials in the cultivation of $P$. ostreatus. Chickpea straw without additives presented the first primordia at 15.3 days of incubation and BE of $68.3 \%$, while the chickpea straw with additives presented the first primordia between 17.8 to 23.2 days, with BE between $55.3 \%$ and $99.8 \%$ (Atila, 2017). Moreover, the values achieved on BS are higher than those obtained when a strain of $P$. ostreatus was grown on bean stubble alone or supplemented in various proportions with dehydrated alfalfa (Medicago sativa L.). The bean stubble alone reached $46.8 \%$ of BE and PR of $0.39 \%$, and when was supplemented, reached between $62.7 \%$ to $84.1 \%$ of $\mathrm{BE}$ and between $0.52 \%$ to $0.70 \%$ of PR (RomeroArenas et al., 2018).

\section{Conclusion}

The best treatment was FCS-3 followed by FCS-5 and FCS-7 treatments that achieved more than $100 \% \mathrm{BE}$, while BS and PS treatments showed $\mathrm{BE}$ that was close to this percentage. The results indicate the possibility of using the fermented chickpea stubble as a substrate in the cultivation of IE-8 strain. Likewise, bean and peanut stubble can be used as a substrate, since they approached $100 \% \mathrm{BE}$, which makes their production profitable.

\section{REFERENCES}

1. Atila, F. (2017). Biodegredation of different agroindustrial wastes through the cultivation of Pleurotus ostreatus (Jacq. ex. Fr) Kummer. Journal of Biology and Environmental Science, 11(31): 1-9.
2. Deshmukh, S.V. and Deshmukh, V.R. (2016). Soybean straw: A promising substrate for cultivation of oyster mushroom. International Journal of Science and Research, (5)3: 1528-1531.

3. Fernandes, A., Barros, L., Martins, A., Herbert, P. and Ferreira, I.C.F.R. (2015). Nutritional characterization of Pleurotus ostreatus (Jacq. ex Fr.) P. Kumm. produced using paper scraps as substrates. Food Chemistry, 169:396-400.

4. Gaitán-Hernández, R., Salmones, D., Pérez, M.R., Mata, G. (2002). Manual práctico del cultivo de setas: aislamiento, siembra y producción. Instituto de Ecología, Xalapa, Ver. México, $56 \mathrm{p}$.

5. Martínez- Carrera, D., Larqué-Saavedra, A., Tovar Palacio, A., Torres, N., Meneses, M.E., Sobal Cruz, M., Morales Almora, P., Bonilla Quintero, M., Escudero Uribe, H., Tello-Salgado, I., Bernabé-González, T., Martínez Sánchez, W. and Mayett, Y. (2016). Contribución de los hongos comestibles, funcionales y medicinales a la construcción de un paradigma sobre la producción, la dieta, la salud y la cultura en el sistema agroalimentario de México. In: Martínez-Carrera D., J. Ramírez Juárez (eds.), Ciencia, Tecnología e Innovación en el Sistema Agroalimentario de México. Editorial del Colegio de Posgraduados-AMCCONACYT-UPAEP-IMINAP, San Luis Huexotla, Texcoco, México, pp. 581-640.6.

6. Mora, V. M. and Martínez-Carrera, D. (2007). Investigaciones básicas, aplicadas y socioeconómicas sobre el cultivo de setas Pleurotus spp en México. In: Sánchez, J.E., D. Martínez-Carrera, G. Mata, H. Leal (eds.), El cultivo de setas Pleurotus spp. en México. El Colegio de la Frontera Sur, Tapachula. pp. 7-26.

7. Pokhrel, C. P., Kalyan, N., Budathoki, U. and Yadav, R.K.P. (2013). Cultivation of Pleurotus sajor-caju using different agricultural residues. International Journal of Agricultural Policy and Research, 1: 019023.

8. Romero-Arenas, O., Valencia-De Ita, M.A., RiveraTapia, J.A., Tello-Salgado, I., Villarreal Espino-Barros, O.A. and Damián-Huato, M.A. (2018). Capacidad productiva de Pleurotus ostreatus utilizando alfalfa deshidratada como suplemento en diferentes sustratos agrícolas. Agricultura, Sociedad y Desarrollo, 15 (2): 145-160.

9. Royse, D. J., Baars, J. and Tan, Q. (2017). Current overview of mushroom production in the world. In: Zied, D. C., A. Pardo-Giménez (eds.), Edible and medicinal mushrooms: Technology and applications. John Wiley and Sons-Blackwell, Nueva York. Pp. 513. http://doi.org/10.1002/9781119149446.ch2.

10.Royse, D.J. and Sánchez, J.E. (2017). Producción mundial de setas Pleurotus spp. con énfasis en países iberoamericanos. In: Sánchez, J.E., D. Royse (eds.). La biología, el cultivo y las propiedades nutricionales y medicinales de las setas Pleurotus spp. El Colegio de la Frontera Sur. Tapachula, Pp.17-25.

11.SIAP. (2018). Servicio de Información Agroalimentaria y Pesquera. Secretaría de Agricultura, Ganadería, Desarrollo Rural, Pesca y Alimentación (SAGARPA). https://nube.siap.gob.mx/cierreagricola/ 